A RCHIWA, BIBLIOTEKI

I MUZEA KOŚCIELNE 109 (2018)

https://doi.org/10.31743/abmk.2018.109.08

JANUSZ A. FRYKOWSKI* - TOMASZÓW LUBELSKI

\title{
Z DZIEJÓW PARAFII UNICKIEJ PW. WNIEBOWZIECIA PAŃSKIEGO W SZAROWOLI W ŚWIETLE XVIII-WIECZNYCH WIZYTACJI KOŚCIELNYCH
}

\section{Wprowadzenie}

Wieś Szarowola położona jest w gminie Tomaszów Lubelski, w północnej części powiatu tomaszowskiego, w województwie lubelskim. Swoimi korzeniami sięga 2. połowy XVI w., skoro już w 1579 r. na gruncie Rogóźna, w miejscu zwanym Porebrody, pop Kunat zaczął osadzać wieś zwaną Szarą Wolą (Szary Kąt) ${ }^{1}$. Właściciel wsi, Jan Zamojski musiał być zadowolony z akcji osadniczej, ponieważ w 1584 r. sołectwo w niej nadał synom tegoż popa. Po ich zarządem wieś rozwijała się dość prężnie, skoro 50 lat później opłacono z niej podymne od 115 chałup 2 .

W okresie staropolskim wieś znajdowała się w województwie bełskim, które do 1462 r. tworzyło oddzielne księstwo, podległe książętom mazowieckim. Po śmierci ostatniego księcia z linii Piastów mazowieckich Władysława II, ziemia bełska, jako odrębne województwo weszła w skład Korony. Pierwotnie województwo to dzieliło się na pięć powiatów: bełski, buski, grabowiecki, horodelski i lubaczowski, przy czym powiaty bełski i lubaczowski w 1531 r. zostały połączone w jeden - bełski ${ }^{3}$. W rezultacie pierwszego rozbioru Polski w 1772 r., Szarowola dostała się pod panowanie Austrii i taki stan utrzymał się do $1809 \mathrm{r}$. Wówczas to, w wyniku powiększenia Księstwa Warszawskiego, wieś znalazła

\footnotetext{
* Janusz Adam Frykowski - dr historii; dyrektor Zespołu Szkół nr 1 im. Bartosza Głowackiego w Tomaszowie Lubelskim.

${ }^{1}$ J. Peter, Z przeszłości miasta kresowego, Zamość 1947, s. 13-14; A. Janeczek, Osadnictwo pogranicza polsko-ruskiego. Województwo betskie od schytku XIV do początku XVII w., Warszawa 1993, s. 163.

${ }^{2}$ Szerzej na dziejów tej wsi zob. J. Niedźwiedź, Leksykon historyczny miejscowości dawnego województwa zamojskiego, Zamość 2004, s. 492.

${ }^{3}$ Z. Gloger, Geografia historyczna ziem dawnej Polski, Kraków 1903, s. 226; Źródła dziejowe, Tom XVIII, Część I, Polska XVI wieku pod względem geograficzno-statystycznym, Tom VII, Część I, Ziemie Ruskie. Ruś Czerwona, oprac. A. Jabłonowski, Warszawa 1902, s. 20.
} 
się w jego granicach. Kolejna zmiana przynależności Szarowoli miała miejsce w 1815 r., kiedy to na kongresie wiedeńskim z ziem Księstwa Warszawskiego utworzono Królestwo Polskie, zależne od Cesarstwa Rosyjskiego. W granicach imperium Romanowów przedmiotowa wieś pozostawała do wybuchu pierwszej wojny światowej.

Rys. 1. Szarowola. Wycinek z mapy F. von Miega, Karte des Königsreiches Galizien und Lodomerien, 1:28800, 1779-1782/ Fig. 1. Szarowola. The map segment F. Von Miega, Karte des Königsreiches Galizien und Lodomerien, 1:28800, 1779-1782

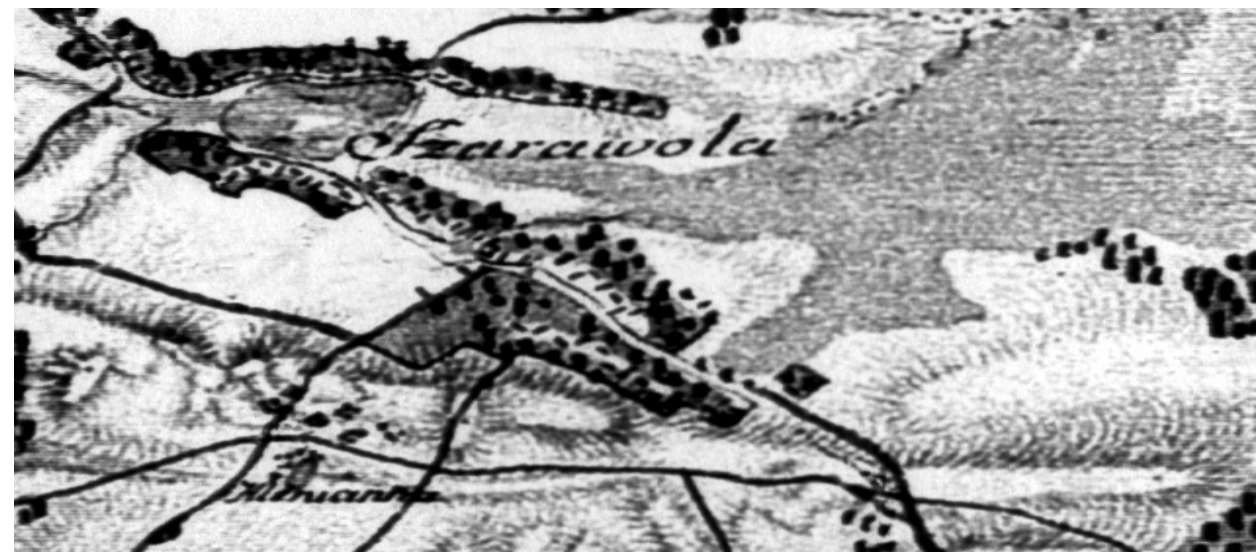

Źródto: Kriegsarchiv Wiedeń, rps. B. IX a, k. 390.

Powyższa ilustracja jest wycinkiem wielkoskalowej mapy Królestwa Galicji i Lodomerii, czyli terytorium Rzeczypospolitej, które zostało włączone do Austrii w wyniku wydarzeń 1770 r., oraz w pierwszym rozbiorze w 1772 r., sporządzonej w latach $1779-1783$ przez mjra Friedricha von Miega. $Z$ analizy ryciny wynika, że w badanym okresie Szarowola była ulicówką, czyli typem wsi jednodrożnej o zwartej zabudowie po obu stronach drogi, położoną w dolinie, wśród niewielkich obszarów leśnych. Niestety niezbyt wyraźnie zaznaczona jest cerkiew, ale można się domyślać, że położona była w środku wsi, co może symbolizować ciemniejszego koloru kwadrat zwieńczony odcinkiem zapewne symbolizującym krzyż na świątyni.

Ze względu na to, że Szarowola położona była w województwie i w powiecie bełskim, jej ludność poddana była oddziaływaniu dwóch funkcjonujących obok siebie diecezji: prawosławnej eparchii chełmskiej (po 1596 r. unickiej) oraz chełmskiej diecezji katolickiej obrządku łacińskiego. Granice administracyjne obu diecezji niemal się pokrywały, więc zamieszkiwała je na pewno ludność obydwu wyznań, a po 1596 r. - zarówno dwóch wyznań, jak i dwóch obrządków ${ }^{4}$.

${ }^{4}$ A. Gil, Prawostawna eparchia chetmska do 1596 r., Lublin-Chełm 1999, s. 167; A. Mironowicz, Struktura organizacyjna Kościoła prawosławnego w Polsce w X-XVIII wieku, w: Kościót prawosławny w Polsce dawniej i dziś, red. L. Adamczuk, A. Mironowicz, Warszawa 1993, s. 48-58; 
Prawosławna diecezja chełmska funkcjonowała do 8 października 1596 r., kiedy to w Brześciu nad Bugiem metropolita Michał Rohaza wraz z częścią hierarchów, w tym władyką chełmskim Dionizym Zbirujskim, ogłosił przyjęcie unii. Hierarcha ten został pierwszym unickim biskupem chełmskim ${ }^{5}$. Unicka diecezja chełmska pierwotnie obejmowała obszar ziemi chełmskiej, województwa bełskiego (bez okolic Lubaczowa), a także licznych enklaw-parafii ${ }^{6}$. Organizacyjnie dzieliła się na dwa oficjalaty (chełmski i bełski), te z kolei na 13 oraz 22 dekanaty. W granicach dekanatów funkcjonowały parafie, których liczba, zależnie od okresu, była różna, np. w 1772 r. było ich 5427. Po pierwszym rozbiorze południowe tereny diecezji, stanowiące około $2 / 3$ jej dotychczasowej powierzchni, zostały zajęte przez Austrię. W ramach dostosowywania organizacji kościelnej do nowego podziału administracyjnego monarchii habsburskiej w 1784 r. tereny te włączono do eparchii lwowskiej i przemyskiej. Dalsze zmiany granic unickiej diecezji chełmskiej nastąpiły na skutek trzeciego rozbioru, w którego wyniku eparchia utraciła tereny położone na prawym brzegu Bugu. Kolejne zmiany granic diecezji nastąpiły podczas wojen napoleońskich, a ostatecznie ukształtowały się po kongresie wiedeńskim. Podlegały jej wówczas wszystkie parafie unickie w Królestwie Polskim oraz parafia w Wolnym Mieście Krakowie ${ }^{8}$.

Po zawarciu unii brzeskiej Cerkiew unicka stała się jedynym legalnym Kościołem ruskim w Rzeczypospolitej. Prawa Cerkwi prawosławnej zostały ponownie uznane dopiero przez sejmy w latach 1607 i 1609. Stosunki między obydwoma Kościołami nie układały się najlepiej, zaś apogeum wrogości miało miejsce w 1623 r., kiedy to został zamordowany Jozafat Kuncewicz, unicki arcybiskup połocki, późniejszy święty i patron unii ${ }^{9}$. Sytuacja nie uległa zmianie nawet po śmierci Zygmunta III Wazy, głównego rzecznika polityki popierania unii i ograniczania praw prawosławia. Dopiero wybór na króla w 1632 r. Władysława IV Wazy doprowadził do uspokojenia stosunków pomiędzy prawosławnymi a unitami. Nowy król w pactach conventach zobowiązał się zezwolić na działalność metropolii kijowskiej, zgodził się też na wybór metropolity według dawnych praw

L. Bieńkowski, Diecezja prawosławna, w: Encyklopedia Katolicka (dalej: EK), t. 3, red. R. Łukaszyk, Lublin 1988, kol. 132.

${ }^{5} \mathrm{O}$ unii brzeskiej zob. E. Likowski, Unia brzeska, Warszawa 1907; H. Dylągowa, Dzieje unii brzeskiej (1596-1918), Warszawa 1996; Czterechsetlecie zawarcia Unii Brzeskiej 1596-1996: materiaty z sesji naukowej zorganizowanej $w$ Toruniu $w$ dniach $28-29$ listopada 1996 r., red. S. Alexandrowicz, T. Kempa, Toruń 1998; K. Soczyński, 400-lecie unii brzeskiej, Warszawa 1996; Dziedzictwo Unii Brzeskiej, red. R. Dobrowolski, M. Zemło, Lublin-Supraśl 2012; Unia brzeska 1596 r. Geneza i skutki. Katalog wystawy, Torun 1997; Unia brzeska. Materiaty z radomskiego sympozjum, red. A. Hejda, Radom 1998; Unia brzeska, geneza, dzieje i konsekwencje w kulturze narodów stowiańskich, red. R. Łużny, F. Ziejka, A. Kępiński, Kraków 1994.

${ }^{6}$ L. Bieńkowski, Organizacja Kościoła Wschodniego w Polsce, w: Kościół w Polsce, t. 2, red. J. Kłoczowski, Kraków 1970, s. 863.

${ }^{7}$ W. Kołbuk, Kościoły wschodnie w Rzeczypospolitej około 1772 r., Lublin 1998, s. 45; tenże, Kościoły wschodnie na ziemiach dawnej Rzeczypospolitej 1772-1914, Lublin 1992, s. 117-125.

${ }^{8}$ Dylągowa, Dzieje unii brzeskiej (1596-1918), s. 94.

${ }^{9}$ A.P. Dydycz, Opisanie odnalezienia relikwii św. Jozafata Kuncewicza na tle jego życia oraz dziejów doczesnych szczątków, „Rocznik Bialskopodlaski”, 12 (2004) s. 159-176. 
i na wyświęcenia biskupów przez patriarchę konstantynopolitańskiego na mocy przywileju królewskiego. Postanowienia te zostały zatwierdzone przez sejm w $1635 \mathrm{r}$. W tym samym roku także unici wystarali się o przywilej, który zagwarantował im dotychczasowy stan posiadania. $Z$ tego też powodu nastąpił podział cerkwi i monastyrów znajdujących się w królewszczyznach pomiędzy unitów i prawosławnych. Tym samym dokonał się i utrwalił formalny podział Kościoła wschodniego w Rzeczypospolitej. Względny spokój między obydwoma wyznaniami zakończył się w 1648 r. wraz z wybuchem wojny z Kozakami i w jej następstwie - w 1654 r. z Rosją. Klęski poniesione przez wojska polskie doprowadziły do wzrostu znaczenia prawosławia i widma całkowitej likwidacji unii. Kościół unicki, choć osłabiony, przetrwał ten burzliwy okres. Kończący wojny rozejm w Andruszowie w 1667 r. pozbawił unitów diecezji smoleńskiej, ale umożliwił im powrót do połockiej. Natomiast utrata na rzecz Rosji lewobrzeżnej Ukrainy wraz z Kijowem osłabiła prawosławie w Rzeczypospolitej. Nie bez znaczenia dla dalszego funkcjonowania unii była przychylna dla niej polityka szlachty, a także osłabienie kozactwa, które dotychczas dawało silne oparcie polityczne i militarne Cerkwi prawosławnej ${ }^{10}$. Niestety, w wyniku zawartego w $1686 \mathrm{r}$. pokoju wieczystego między Polska a Rosją, metropolicie kijowskiemu zostało przyznane zwierzchnictwo nad Kościołem prawosławnym w Polsce, a ludność prawosławna otrzymała wolność wyznania i prawo swobodnego kontaktowania się z metropolią w sprawach cerkiewnych. Konsekwencją tych postanowień były częste interwencje rządu rosyjskiego w sprawach o naruszenie praw prawosławia, bardzo często domniemane.

W wyniku rozbiorów unici znaleźli się w zaborze rosyjskim i austriackim. Pod rządami habsburskimi zwano ich grekokatolikami i traktowano na równi z rzymskimi katolikami. Oba obrządki zostały objęte systemem rządów józefińskich, polegających na bardzo silnym podporządkowaniu Kościoła państwu. Zdecydowanie gorzej przedstawiała się ich sytuacja w zaborze rosyjskim, gdzie władze uważały, że unię zawarto nieprawnie i traktowały unitów jako odłączonych przemocą od Kościoła prawosławnego. Planowa akcja nawracania unitów zaczęła się już po II rozbiorze Polski, zaś jej efektem było w 1839 r. przyłączenie Kościoła unickiego w granicach Cesarstwa Rosyjskiego do Cerkwi prawosławnej. Funkcjonowanie Kościoła unickiego w całym zaborze rosyjskim zostało ostatecznie przerwane w 1875 r., kiedy to car Aleksander II, ogłosił jego włączenie do Cerkwi prawosławnej.

Jednostką ułatwiającą zarząd eparchiami Kościołów wschodnich była protopopia (protoprezbiteria), odpowiednik dekanatu w Kościele łacińskim, na czele której stał protopop. Początkowo sprawował on władzę sądowniczą, którą utracił w XVIII w. Dokładna data utworzenia protopopii tomaszowskiej jest nieznana. Pewne jest natomiast, że miało to miejsce pod koniec XVII w., o czym mogą świadczyć wykazy parafii diecezji chełmskiej z lat 1619-1620 i dekanatów z lat 1683-1685, w których trzy tomaszowskie parafie unickie są jeszcze przyporząd-

\footnotetext{
${ }^{10}$ Bieńkowski, Organizacja Kościoła wschodniego w Polsce, s. 852-853.
} 
kowane do dekanatu tyszowieckiego ${ }^{11}$. Po raz pierwszy protoprezbiteria tomaszowska odnotowana została w rejestrze cerkwi diecezji chełmskiej i bełskiej z 1696 r. Dekanat tomaszowski, podobnie jak dwa inne dekanaty - horodelski i zamojski, utworzony został w drodze podziału większych jednostek. Protopopia tomaszowska powstał na skutek podziału protoprezbiterii tyszowieckiej. Nowo utworzona jednostka administracyjna w początkowym okresie funkcjonowania obejmowała swoim zasięgiem 23 parafii ${ }^{12}$. Powiększenie dekanatu o kolejne trzy parafie nastąpiło między 1696-1772 r. Jak wyliczył Witold Kołbuk, około roku 1772 protopopia ta liczyła 26 parafii i powiększyła się o kolejne: Ciotuszę, Wieprzowe Jezioro, Bełżec, Gródek, Krupiec, Lipsko i Podhorce ${ }^{13}$. Dość znaczne zmiany w sieci parafialnej protopopi tomaszowskiej nastąpiły zapewne pod koniec XVIII i na początku XIX w. Wówczas to przy okazji kasowania niektórych parafii, zmieniono także i przynależność organizacyjną niektórych parafii ${ }^{14}$. Z Konsygnacji duchowieństwa dekanatu tomaszowskiego do konsystorza na dzień 31 stycznia 1811 podanej, wynika że w tym roku dekanat liczył tylko 7 parafii (Tomaszów, Sopot-Majdan Sopocki, Łosiniec, Przeorsk, Chodywańce, Szlatyn i Typin $)^{15}$. Taka organizacja dekanatu przetrwała do 1850 r., gdyż jak wynika z wykazu ludności w parafiach na dzień 31 grudnia 1851 r. do dekanatu tomaszowskiego została dołączona pobliska parafia w Tarnawatce ${ }^{16}$. Ostatnia zmiana organizacyjna protopopi tomaszowskiej, miała miejsce w latach 60. XIX wieku. W związku z przygotowaniami do skasowania unii w diecezji chełmskiej, dokonano ponownego podziału dekanalnego według powiatów. Znaczyło to, że z parafii leżących na terenie danego powiatu tworzono dekanaty przyjmujące nazwę od miasta powiatowego. W ten sposób powstało 12 dekanatów, a wśród nich dekanat

${ }^{11}$ A. Gil, Chetmska Diecezja Unicka w okresie rząów biskupa Jakuba Suszy (1649-1687), w: Sztuka sakralna i duchowość pogranicza polsko-ukraińskiego na Lubelszczyźnie (Materiaty z Międzynarodowej Konferencji ,Sztuka Sakralna Pogranicza”, Lublin 13-15.10.2005 r.), red. S. Batruch, R. Zilionko, Lublin 2005, s. 61-66; tenże, Chetmskie diecezje obrzadku wschodniego. Zagadnienia organizacji terytorialnej w XVII i XVIII wieku, w: Polska-Ukraina. 1000 lat sąsiedztwa, t. 5, red. S. Stępień, Przemyśl 2000, s. 43-44.

12 Jak informuje Regestr Cerkwiow w Diocezji Chetmskiey Betzskiey bendacych a w jedności Świętej z Kosciołem Rzymskim zostaiących y iak wiele do Ktorey Protoprezbiterji Kapłanów należeć ma, R. 1696 Juni 3 dnia iest spisany w skład dekanatu tomaszowskiego wchodziły trzy parafie z Tomaszowa i po jednej z Rogóźna, Szarowoli, Łosińca, Maził, Łaszczówki, Rudy, Przeorska, Korhyń, Jarczowa, Jurowa, Wierszczycy, Szlatyna, Hubinka, Rzeczycy, Ulhówka, Żernik, Ratyczowa, Posadowa, Steniatyna i Nedeżowa, wg. Gil, Chetmskie diecezje obrządku wschodniego. Zagadnienia organizacji terytorialnej w XVII i XVIII wieku, s. 52.

${ }^{13}$ Kołbuk, Kościoły wschodnie w Rzeczypospolitej, s. 309-310.

${ }^{14}$ Parafie takie zwano też ,skasowanymi” lub „,przyłączonymi”. Zob. J. Lewandowski, Greckokatolicka diecezja chetmska $w$ realiach polityczno-ustrojowych Ksiesstwa Warszawskiego, „Annales Universitatis Mariae Curie-Skłodowska”, Sectio F, Historia, vol. LXII, Lublin 2007, s. 79.

${ }^{15}$ Archiwum Państwowe w Lublinie (dalej: APL), Chełmski Konsystorz Greckokatolicki (dalej: ChKGK), sygn. 146, s. 151.

16 Tamże, sygn. 147, s. 50, 152, 245; sygn. 148, s. 27, 103; sygn. 149, s. 85-86, 261; sygn. 150, s. 23,322 ; sygn. 151 , s. $56,137,417,510$; sygn. 154 , s. $89-90$, 478; sygn. 228 , k. 8 . 
tomaszowski liczący 30 parafii ${ }^{17}$. W takiej organizacji protopopia tomaszowska przetrwała do 1875 r., czyli do kasacji unii.

Ogromne znaczenie dla funkcjonowania Cerkwi unickiej miał synod w Zamościu, który odbył się w roku 1720 r. i wprowadził nowe oraz usankcjonował wprowadzone wcześniej zmiany, upodabniające obrządek unicki do łacińskiego. Wówczas to ustanowiono uroczystość Bożego Ciała, codzienne msze święte, jednolitą administrację sakramentów, wprowadzono monstrancje do wystawiania Najświętszego Sakramentu na ołtarzu oraz miejsce do jego przechowywania tzw. tabernakulum. W czasie nabożeństw zaczęto używać organów, a podczas procesji chorągwi, sztandarów, feretronów i dzwonków. Ponadto odprawiano drogę krzyżową, gorzkie żale, odmawiano różaniec i koronki. Należy nadmienić, że unici do cerkwi wstawili ławki, konfesjonały oraz boczne ołtarze. Wprowadzone zmiany spowodowały, że cerkwie wznoszone w drugiej połowie XVIII w. były najczęściej pozbawione ikonostasu. Kapłanom nakazano głosić kazania i wykładać katechizm, pozwolono także nosić takie same sutanny, jak księżom katolickim oraz golić zarost. Synod zobowiązał też kapłanów do posyłania synów na naukę do szkół. Wprowadzono wówczas także dalsze ograniczenia władzy dziekanów, która sprowadzała się odtąd jedynie do sprawowania przez nich funkcji administracyjno-kontrolnych ${ }^{18}$.

Podstawowymi źródłami do przedmiotowego artykułu są protokoły z wizytacji parafii. Omówienie wizytacji, jako źródła historycznego, oraz literatury do tego zagadnienia można znaleźć w pracach Stanisława Litaka, Hieronima Edwarda Wyczawskiego OFM i ks. Stanisława Librowskiego ${ }^{19}$. Istotne znaczenie akt wizytacji dla poruszanego zagadnienia wynika z faktu, że przedstawiają one stan i potrzeby kościoła parafialnego, beneficjum plebana, spisy inwentarza kościoła, cmentarza i budynków gospodarczych.

Artykuł przedstawia dzieje parafii unickiej pw. Wniebowstąpienia Pańskiego w Szarowoli w XVIII w. Pewne jest, że wspólnota unicka w tej wsi funkcjonowała już w XVII w. Niestety szczupłość danych dla tego okresu nie pozwala na odtworzenie jej działalności. Braki źródeł wynikają z faktu, że w tym czasie rzadziej sporządzano protokoły wizytacji, albo też do naszych czasów takie się nie zachowały na skutek m.in. zniszczeń $\mathrm{w}$ wyniku działań wojennych oraz klęsk

${ }^{17}$ Kołbuk, Kościoły wschodnie na ziemiach dawnej Rzeczypospolitej, s. 102.

${ }^{18}$ E. Likowski, Dzieje Kościoła unickiego na Litwie i Rusi w XVIII $i$ XIX wieku uważane głównie ze względu na przyczyny jego upadku, t. 1, Warszawa 1906, s. 38-59; G. Chruscewicz, Istorija zamojskago sobora (1720 goda), Wilno 1880, s. 155-267; A. Gil, I. Skoczylas, Kościoły wschodnie $w$ państwie polsko-litewskim $w$ procesie przemian i adaptacji: metropolia kijowska $w$ latach 14581795, Lublin-Lwów 2014, s. 325-342.

${ }^{19}$ P. Sygowski, Wizytacja cerkwi unickiej diecezji chelmskiej przeprowadzonej w latach 17201725 przez biskupa chetmskiego i betskiego Józefa Lewickiego, „Studia Archiwalne”, 2 (2007) s. 199-232; S. Litak, Akta wizytacyjne parafii z XVI-XVIII wieku, jako źródto historyczne, „Zeszyty Naukowe KUL", 5 (1962) nr 3, s. 43; H.E. Wyczawski, Wprowadzenie do studiów w archiwach kościelnych, Warszawa 1956; S. Librowski, Wizytacje diecezji wrocławskiej, cz. 1, Wizytacje diecezji kujawsko-pomorskiej, t. 1, Opracowanie archiwalno-źródłoznawcze, z. 1, Wstęp ogólny, „Archiwa, Biblioteki i Muzea Kościelne”, 8 (1964) s. 5-186. 
żywiołowych ${ }^{20}$. Nie bez znaczenia dla tego zjawiska był także brak skłonności księży Kościoła wschodniego do stałego dokumentowania jego organizacji i swojej działalności, gdyż dominowała wśród nich ustna kultura prawna.

\section{Powstanie parafii w Szarowoli}

Parafia jest najmniejszą terytorialnie jednostką organizacyjną Kościoła. Obejmuje obszar zamieszkały przez określoną grupę ludzi, dla której kapłan, wyposażony w specjalne uprawnienia, wypełnia posługi duszpasterskie ${ }^{21}$.

Dla określenia czasu powstania kościołów parafialnych najbardziej wiarygodne są dokumenty fundacyjne i erekcyjne ${ }^{22}$. W przypadku Szarowoli, mimo że nieznany jest żaden z przedmiotowych dokumentów, można przypuszczać, że w XVI w. była tam świątynia prawosławna, mimo że wzmianki o cerkwi w tej wsi pochodzą z końca następnego stulecia. Do takiego wniosku upoważnia osoba zasadźcy tej wsi, popa Kunata ${ }^{23}$. Niestety z podobnych przyczyn, nie znamy także daty utworzenia tam parafii unickiej. Pierwsze dane potwierdzające jej funkcjonowanie w Szarowoli pochodzą z 2. połowy XVII stulecia. Niestety, nie zachowały się informacje dotyczące wprowadzania unii w tej parafii. Wiadomo natomiast, że w siedzibie dekanatu, do którego należała szarowolska wspólnota wiernych, Tyszowcach pomiędzy jej zwolennikami i przeciwnikami doszło do zamieszek na tle religijnym. W latach 30 . i 40 . XVII wieku miały one bardzo gwałtowny przebieg, włącznie z siłowym odbieraniem świątyń, niszczeniem wyposażenia, napadami na kapłanów i wiernych obu stron ${ }^{24}$. Można się domyślać, że zarówno w siedzibie, jak i w podległych parafiach, zajścia mogły mieć podobny przebieg.

Należy sądzić, że w pierwszym okresie funkcjonowania parafia w Szarowoli organizacyjnie przynależna była do dekanatu tyszowieckiego. Wiadome bowiem jest, że w $1573 \mathrm{r}$. istniała w Tyszowcach protopopia prawosławna ${ }^{25}$. Można więc sądzić, że podobnie jak struktura terytorialna i organizacyjna Cerkwi prawosławnej po unii nie uległa poważniejszym zmianom, podobnie było i w przypadku dekanatu tyszowieckiego ${ }^{26}$. Pewna informacja o przynależności tej parafii do

${ }^{20} \mathrm{Na}$ temat zniszczeń w diecezji chełmskiej w wyniku wojen z połowy XVII w. zob. Gil, Chetmska Diecezja Unicka w okresie rządów biskupa Jakuba Suszy (1649-1687), s. 61-66.

${ }^{21}$ M. Nowodworski, Parafia, w: Encyklopedia kościelna, t. 16, red. M. Nowodworski, Warszawa 1892, s. 200; J. Koziej, Parafia, EK, t. 14, red. E. Gigilewicz, Lublin 2010, kol. 1324-1326.

${ }^{22}$ Zasadniczą funkcją dokumentu fundacyjnego było określenie materialnych podstaw funkcjonowania świątyni, bez których nie mogłaby ona spełniać swoich zadań. Zob. W. Wójcik, Fundacja, EK, t. 5, red. L. Bieńkowski, Lublin 1989, kol. 760-761.

${ }^{23}$ Patrz przypis nr 1.

${ }^{24}$ Gil, Chetmska diecezja unicka 1596-1810, s. 73-74.

${ }^{25}$ AGAD, ASK, sygn. 36, k. 307v.

${ }^{26}$ Wprowadzenie unii nie odbyło się w dekanacie bez zamieszek na tle religijnym między jej zwolennikami i przeciwnikami. W latach 30. i 40. XVII wieku miały one bardzo gwałtowny przebieg, włącznie z siłowym odbieraniem świątyń, niszczeniem wyposażenia, napadami na kapłanów i wiernych obu stron. A. Gil, Chetmska diecezja unicka 1596-1810. Dzieje i organizacja. Studia i materiały z dziejów chrześcijaństwa wschodniego w Rzeczpospolitej, Lublin 2005, s. 73-74. Więcej na tema wprowadzania unii patrz: K. Chodynicki, Kościół prawosławny a Rzeczpospolita Polska. 
protopopii tyszowieckiej pochodzi z wykazu dekanatów unickiej diecezji chełmskiej $\mathrm{z}$ lat 1683-168527. Zmiana przynależności organizacyjnej parafii w Szarowoli i włączenie jej do dekanatu tomaszowskiego poświadcza Regestr Cerkwiow w Diocezji Chetmskiey Betzkiey bendacych a wjedności Świętey z Kościolem Rzymskim zostaiacych y iak wiele do Ktorey Protoprezbiterji Kaptanow należeć ma, $R$. 1696 Junii 3 dnia iest spisany, który niestety poza potwierdzeniem funkcjonowania tam świątyni, nie podaje żadnych bliższych szczegółów ${ }^{28}$.

Pewne jest, że parafia unicka w Szarowoli funkcjonowała prawie przez cały XVIII w., a przynajmniej przez trzy jego ćwierci, co potwierdza katalog zmarłych kapłanów, podając, że 31 marca 1775 r. zmarł duchowny tej parafii Bazyli Obuchowicz ${ }^{29}$. Zapewne po jego śmierci, parafia została przez władze austriackie zdegradowana do cerkwi filialnej i włączona do parafii w Łosińcu ${ }^{30}$. Taki scenariusz potwierdzają badania W. Kołbuka, który stwierdził, że likwidacja wielu mniejszych parafii i przekształcenie ich w cerkwie filialne miała miejsce w okresie józefińskim, kiedy znaczna część diecezji chełmskiej znajdowała się pod zaborem austriackim ${ }^{31}$.

\section{Cerkiew parafialna}

Miejscem niezbędnym do sprawowania obrzędów religijnych jest świątynia. Budowla o takim charakterze bardzo często jest wyposażona w liczne przedmioty służące wyłącznie kultowi religijnemu, takie jak ołtarze, obrazy, relikwie czy kadzielnice. Ich obecność wyraża sakralny charakter miejsca, są one też niezbędne przy wielu obrzędach.

Pierwszy znany opis świątyni pw. św. Wniebowzięcia Pańskiego w Szarowoli znajduje się w protokole wizytacji parafii z czasów bpa Józefa Lewickiego z $1720 r .{ }^{32}$ Niestety informacje zawarte tam są bardzo lakoniczne i ograniczają się do stwierdzenia, że świątynia „w ścianach dobra, $w$ dachach potrzebuje reperacji”. Ponadto dodane jest, że na dzwonnicy znajdował się jeden dzwon. Niestety, nie ma żadnych innych informacji dotyczących wyglądu jak i stanu dzwonnicy. Mimo że w źródle nie podano, z jakiego materiału zbudowana była zarówno cerkiew jak i dzwonnica, można przypuszczać, że były to budowle drewniane, pokryte gontem lub słomą, gdyż wówczas z takiego materiału stawiano najczę-

Zarys historyczny 1370-1632, Warszawa 1934; B. Kumor, Geneza i zawarcie unii brzeskiej, w: Unia brzeska, geneza, dzieje i konsekwencje w kulturze narodów stowiańskich, red. R. Łużny, F. Ziejka,

A. Kępiński, Kraków 1994, s. 26-44.

${ }^{27}$ Gil, Chetmskie diecezje obrzadku wschodniego, s. 50.

${ }^{28}$ Tamże, s. 52.

${ }^{29}$ APL, ChKGK, sygn. 636, s. 820.

${ }^{30} \mathrm{O}$ dalszych dziejach cerkwi filialnej w Szarowoli zob. J.A. Frykowski, Dzieje parafii unickiej pw. św. Michała w Łosińcu do 1875 r., „Historia i Świat”, 4 (2015) s. 237-260.

${ }^{31}$ W. Kołbuk, Duchowieństwo unickie w Królestwie Polskim 1835-1875, Lublin 1992, s. 15-17.

В. Слободян, Церкви Холмскоі епархї, Львів 2005, s. 187.

${ }^{32}$ APL, ChKGK, sygn. 101, k. 24. 
ściej budowle sakralne nie tylko we wsiach, ale także i w miastach ${ }^{33}$. Niewiele więcej w tym zakresie można się dowiedzieć z informacji o 23 lata późniejszej. Dokonujący 5 grudnia 1743 r., wizytacji dziekan Jan Łużecki zapisał w protokole „Cerkiew bardzo mizerna, we wszystkim reperacji potrzebuje"34. Dzięki temu zapisowi można być pewnym, że pomiędzy rzeczonymi wizytacjami jakichś większych remontów tej świątyni nie przeprowadzono. Nową informacją jest natomiast to, że przybył jeszcze jeden dzwon na dzwonnicy: w sumie było ich dwa. Ostatnich XVIII-wiecznych, bardzo istotnych wiadomości o świątyni, dostarcza wpis, sporządzony przez ks. Maksymiliana Ryłłę, biskupa chełmskiego z $1761 \mathrm{r}^{35}$ Hierarcha odnotował, że cerkiew „de nova ordice erecta sub tempus visitationis generalis benedicta, in qua Nulla ad Celebrandam misam ordiamenta reperuintur qua Ritus Parochus cum suis Parachianis debit"36. Nieco więcej o wyglądzie świątyni można się dowiedzieć dopiero z protokołu wizytacji przeprowadzonej w 1811 r., zakładając, że była to ta sama budowla ${ }^{37}$. Wizytator, dziekan Jan Panasiński napisał, że świątynia: „,przyzwoicie tylko kapliczką nazwać się może, ponieważ szczupła i na zrębie kwadratowym tylko dach i krzyżyk. W środku ozdoba nieliczna i staroświecka". Obrazu zaniedbania dopełniały zdezelowany parkan i resztki dzwonnicy, z której zachowały się jedynie słupy.

Wyznacznikiem kondycji i zamożności kościoła, oprócz okazałości bryły świątyni i jej uposażenia, jest także zasobność w utensylia. Po raz pierwszy o naczyniach liturgicznych w cerkwi szarowolskiej informuje protokół powizytacyjny z $1720 \mathrm{r} .{ }^{38} \mathrm{~W}$ źródle tym wymieniona jest drewniana pozłacana puszka pro conservando venerabili, cynowy kielich i patena oraz mosiężna łyżeczka ${ }^{39}$. Z szat

${ }^{33}$ J. Górak, Kościoły drewniane Zamojszczyzny, Zamość 1986, s. 7-23; tenże, Dawne cerkwie drewniane w dawnym województwie zamojskim, Zamość 1984, passim.

${ }^{34}$ APL, ChKGK, sygn. 107, k. 263.

${ }^{35}$ Tamże, sygn. 110 , s. 488.

${ }^{36}$ Cerkiew w nowym stylu (porządku) wzniesiona, poświęcona podczas wizytacji generalnej, w której nie ma żadnego wyposażenia do odprawiania mszy świętej, jakiego potrzebuje ruski proboszcz (paroch) ze swoimi parafianami.

${ }^{37}$ APL, ChKGK, sygn. 139, k. 115-115v.

${ }^{38}$ Tamże, sygn. 101, k. 24.

${ }^{39}$ Puszka - naczynie w kształcie kielicha do przechowywania chleba eucharystycznego.

Patena (dyskos) - jest to złoty, pozłacany lub wykonany z innego drogocennego metalu mały talerzyk, na którym kapłan kładzie chleb eucharystyczny (prosforę). Podczas obrzędu przygotowania darów ofiarnych symbolizuje żłobek betlejemski, jak również pojednanie i zjednoczenie wszystkich ludzi wierzących w Jezusa.

Łyżeczka - zwana w liturgicznych księgach lawyna, służy do udzielania wiernym komunii świętej. Ma być wykonana z tego samego materiału, co kielich i dyskos. Symbolizuje kleszcze, którymi Serafin wziął żarzący się węgiel z ołtarza Bożego i oczyścił nim usta proroka Izajasza. Podobnie kapłan przy pomocy łyżeczki udziela wiernym Komunii Świętej i oczyszcza ich grzechy. „Przenajświętsze Ciało i Krew Pańska, niejako żarzący się węgiel, oczyszczają ciało i duszę tych, którzy wierzą w naukę Chrystusa" - są to słowa z modlitwy na poświęcenie łyżeczki liturgicznej. Zob. A. Markunas, T. Uczitiel, Popularny słownik sakaralizmów polskich i ukraińskich, Poznań 2001, s. 59, 79, 92. 
kielicha wymieniony jest korporał, a do przekrycia prestołu antymins ${ }^{40}$. Zmiany jakie zaszły w tym zakresie w ciągu 23 lat pokazuje protokół wizytacji z $1743 \mathrm{r}^{41}$ Ze źródła wynika, że jedyną zmianą było zastąpienie drewnianej puszki cynową, oraz mosiężnej łyżeczki na cynową. Ponadto jest informacja, że antymins został zakupiony przez nieżyjącego już bpa Józefa Lewickiego.

Każde nabożeństwo wymaga odpowiedniej oprawy, do której potrzebne są różnorodne przedmioty, dopełniające i uświetniające jego przebieg. Jak pokazują protokoły wizytacji z 1720 i 1743 r. cerkiew była dość uboga w te utensylia ${ }^{42}$. Na początku należy zaznaczyć, że w cerkwi był tylko jeden „wielki i to niefundamentalny" ołtarz, do przykrycia którego, zależnie od czasu, było od sześciu do dziesięciu „obrusów i chust różnych” oraz dwie harusowe zasłonki ${ }^{43}$. Całości skromnego wyposażenia dopełniał mosiężny trybularz, dwa blaszane lichtarze i dzwonek do elewacji (mszalny) ${ }^{44}$.

Szaty liturgiczne, zwane także paramentami (od paramenta - szaty ozdobne), to rodzaj odzieży stosowanej w czasie liturgii, mającej na celu określenie i zaznaczenie funkcji osoby ją noszącej. W tradycji bizantyjskiej wyróżnia się pięć kolorów szat liturgicznych: białą (srebrną), symbolizującą światłość Chwały Bożej i oświecenie umysłu, używaną w czasie największych świąt (np. Paschy Zmartwychwstania Pańskiego); żółtą (złotą), symbolizującą aniołów, najczęściej wykorzystywaną w ciągu roku liturgicznego; czerwoną, symbolizującą szatę, w którą był ubrany Chrystus przed Piłatem oraz krew męczenników (był to kolor właściwy dla okresu Wielkiego Postu i uroczystości pogrzebowych); niebieską, używaną podczas świąt maryjnych oraz zieloną, stosowaną raz $\mathrm{w}$ roku podczas Zesłania Ducha Świętego ${ }^{45}$.

Wiadomości o szatach liturgicznych w cerkwi szarowolskiej dostarczają protokoły wizytacji z 1720 i $1743 \mathrm{r}^{46}$ Podobnie jak w przypadku wyposażenia ołtarza, tak i w przypadku zasobności w szaty liturgiczne cerkiew była bardzo uboga. Zarówno podczas pierwszej jak i drugiej wizytacji w protokole wymieniony jest tylko jeden aparat, pierwszy raz z materiału tureckiego, a drugi ,kitajkowy żół-

${ }^{40}$ Antymins - jedwabna lub płócienna chusta przedstawiająca scenę złożenia Chrystusa do grobu rozkładana na prestole (najświętsze miejsce w ołtarzu cerkwi) do sprawowania Eucharystii.

Korporał - lniane płótno, na którym stoi kielich i patena z hostią w czasie mszy świętej. Zob. Markunas, Uczitiel, Popularny stownik sakaralizmów polskich i ukraińskich, s. 12-13, 53.

${ }^{41}$ APL, ChKGK, sygn., sygn. 107, k. 263.

${ }^{42}$ Tamże, sygn. 101, k. 22; sygn. 107, k. 263.

${ }^{43}$ Arus (harus) - tkanina wełniana lub półwełniana, różnej szerokości, używana w Polsce XVII-XVIII w. Zob. I. Turnau, Słownik ubiorów. Tkaniny, wyroby pozatkackie, skóry, broń i klejnoty oraz barwy znane w Polsce od średniowiecza do poczatku XIX w., Warszawa 1999, s. 16.

${ }^{44}$ Trybularz - kadzielnica. Zob. Markunas, Uczitiel, Popularny stownik sakaralizmów polskich i ukraińskich, s. 113.

${ }^{45}$ B. Snela, Kolory liturgiczne, EK, t. 9, red. B. Migut, Lublin 2002, kol. 385-386.

${ }^{46}$ APL, ChKGK, sygn. 101, k. 22; sygn. 107, k. 263. 
ty ze wszystkim porządkiem" ${ }^{47}$. Ponadto w źródłach jest jeszcze kolejno mowa o jednej i dwóch albach oraz dwóch paskach ${ }^{48}$.

Niezbędnym elementem wyposażenia każdej świątyni, oprócz argentariów i szat liturgicznych, były także księgi liturgiczne. Dzięki nim sprawowana liturgia jest jednolita i zgodna z wyznawaną wiarą. Obok nich występują tzw. książki pobożne, które zawierają teksty modlitw i nabożeństw prywatnych.

Pierwszych danych o zasobności cerkwi w Szarowoli w księgi liturgiczne i cerkiewne dostarcza protokół wizytacji z 1720 r. ${ }^{49}$ Według tego źródła w świątyni było osiem ksiąg, zarówno rękopisów, jak i drukowanych. Wśród tych pierwszych wymienione są: Ewangelia, czasosłow wielki, psałterz, służebnik i trebnik ${ }^{50} . Z$ rękopisów paroch miał do dyspozycji apostoł, oktoich i prażnię ${ }^{51}$. Kolejnych danych o księgach cerkiewnym dostarcza protokół wizytacji z $1743 \mathrm{r}^{52} \mathrm{Z}$ zapisu w źródle wynika, że od poprzedniej wizytacji ubył drukowany trebnik i ręcznie pisana prażnia, a przybył jeszcze jeden oktoich w rękopisie. Nową informacją jest także miejsce wydania służebnika i czasosłowu - Lwów ${ }^{53}$.

${ }^{47}$ Aparat - komplet przyborów i szat potrzebnych przy odprawianiu ceremonii.

Kitajka - cienka, dość gęsta, gładka tkanina jedwabna o splocie płóciennym, jednobarwna lub mieniąca się. Najprostsza i najpospolitsza z tkanin jedwabnych. Wyrabiana na Wschodzie, w XVII w. Importowana do Polski z Turcji. Za Stanisława Augusta wytwarzana w Gdańsku.

Turecczyzna - tkanina przetykana złota lub srebrna nicią. Zob. Turnau, Stownik ubiorów, s. 15, 87, 191.

${ }^{48}$ Pas - element szat kościelnych używanych podczas Mszy św. Zob. Markunas, Uczitiel, Popularny słownik sakaralizmów polskich i ukraińskich, s. 78.

${ }^{49}$ APL. ChKGK, sygn. 101, k. 24.

${ }^{50}$ Czasosłow - księga niezbędna dla psalmisty oraz chóru cerkiewnego przy odprawianiu codziennych nabożeństw, zawiera teksty niezmienne i zmienne, odnoszące się do liturgii cyklu tygodniowego lub rocznego z podaniem kalendarza liturgicznego.

Psałterz - część księgi liturgii zawierająca psalmy, podzielona na różne dni i pory dnia w cyklu czterotygodniowym.

Służebnik - księga przeznaczona dla diakonów i prezbiterów Kościoła wschodniego, zawiera porządek nabożeństw i krótkie uwagi dla chóru lub psalmisty.

Trebnik - zbiór modlitw okazjonalnych i rytuałów towarzyszących posługom religijnym w Kościele wschodnim. Zawiera porządek udzielania sakramentów, sakramentaliów, błogosławieństw. Zob. Markunas, Uczitiel, Popularny stownik sakaralizmów polskich i ukraińskich, s. 25, 92, 100. Prażnia zapewne była to lokalna nazwa minieji prazdniczej. Zob. Trefołoj (minieja prazdnicznaja) książka cerkiewna, zawierająca wybór tekstów formularzy świątecznych większych świąt wyjętych z minei miesięcznej. Zob. O. Narbutt, Historia i typologia ksiag liturgicznych bizantyńsko-stowiańskich. Zagadnienie identyfikacji wedtug kryterium treściowego, Warszawa 1979, s. 128.

${ }^{51}$ Apostoł - księga zawierająca dzieje i listy apostołów.

Oktoich - księga zawierająca materiał liturgiczny przeznaczony dla chóru i psalmisty podczas nabożeństw w cerkwi w ciągu tygodnia oraz w ciągu r. według ośmiu tonacji śpiewu liturgicznego w cyklu ośmiotygodniowym. Zob. Markunas, Uczitiel, Popularny stownik sakaralizmów polskich i ukraińskich. s. 13, 73-74.

${ }^{52}$ APL, ChKGK, sygn. 101, k. 263.

${ }^{53}$ We Lwowie były dwie drukarnie: Józefa Szmulińskiego, działająca w latach 1687-1688 i drukarnia przy klasztorze bazyliańskim, działająca w latach 1700-1708. Zob. O. Narbutt, Historia i typologia ksiąg liturgicznych bizantyńsko-stowiańskich, s. 41. 


\section{Uposażenie duchowieństwa}

Duchowni sprawujący posługę duszpasterską w parafiach byli uprawnieni do posiadania kościelnego beneficjum, które dawało im określone dochody. Beneficjum plebańskie składało się z nieruchomości: ziemi uprawnej, łąk, ogrodów, budynków oraz z różnego rodzaju praw majątkowych: czynszów, najmu domów, propinacji, mesznego, stołowego i dziesięcin (iskopu) ${ }^{54}$. Uzupełnienie dochodów parocha stanowiły serwituty: wolny wyrąb drewna w lasach na opał i budowę, połów ryb oraz korzystanie z pastwisk. Ważnym źródłem dochodów były także opłaty iura stolae . $^{55}$.

Niestety, nieznane jest pierwotne uposażenie parafii pw. Wniebowzięcia Pańskiego w Szarowoli. Pierwszych danych w tym zakresie dostarcza protokół wizytacji z $1720 \mathrm{r}^{56} \mathrm{Na}$ uposażenie parocha składała się ćwierć gruntu ornego z łąką i przymiarkiem, położonych przy miedzy pola Jacka Bratoszka, „kawałek pola” o nazwie Zbytek i niwka leżąca pod nieokreślonym Ochwatem $^{57}$. Ponadto paroch miał prawo wybierania dziesięciny w wymiarze pół kopy z ćwierci gruntu. Bardziej szczegółowe dane o uposażeniu zawiera wizytacja z $1743 \mathrm{r}^{58}$ Wcześniej wspomniana ćwierć nosiła nazwę Tyczyłowska, zaczynała się „ode wsi, a kończyła za wsią, między miedzami, z jednej strony Rusina, a z drugiej Daczowska i ta ćwierć tylko na dwie ręce, w trzeciej zarasta". Ćwierć ta była nadana 1 lipca 1701 r. przez podstolinę w zamian za mszę jedną tygodniowo, która miała być odmawiana przez „kapłana i jego sukcesorów”. W przypadku niwki jest zapis, że znajdowała się „pod dzikim Filapem, od miedzy Jacka Bartoszka”. Wielkość całego gruntu została określona „na korcy osiem miary zamojskiej, z tym że same piaszczyste góry i doły" ${ }^{99}$. Oprócz tego było dwa kawałki łąki, jedna obok ćwierci

${ }^{54}$ Meszne - rodzaj daniny rocznej, składanej proboszczowi przez parafian w formie czynszu pieniężnego lub w naturze (zapewne zobowiązującej go do odprawiania mszy).

Stołowe - rodzaj czynszu płaconego proboszczowi od domów. Zob. A. Zajda, Nazwy staropolskich powinności feudalnych, danin i opłat (do 1600 r.), Warszawa-Kraków 1979, s. 126, 186.

Iskop - danina oddawana w zbożu. Zob. J. Kość, Stownictwo regionalne w XVII-XVIII-wiecznych księgach miejskich wschodniej Lubelszczyzny, „Studia językoznawcze”, 13 (1988) s. 73; J. Półćwiartek, $Z$ badań nad rola gospodarczo-społeczna plebanii na wsi pańszczyźnianej ziemi przemyskiej i sanockiej w XVI-XIX wieku, Rzeszów 1974, s. 93.

${ }^{55}$ Prawo do pobierania opłat iure stolae wynikało ze spełniania przez duchownych określonych posług religijnych, takich jak: chrzest, zapowiedzi, ślub, pogrzeb i błogosławieństwa kobiety po ślubie i chrzcie dziecka, tzw. wywody. Zob. M. Karbownik, Ofiary iura stolae na ziemiach polskich w latach 1285-1918, Lublin 1995; tenże, Opodatkowanie duchowieństwa i dóbr kościelnych na ziemiach polskich w okresie zaborów 1772-1918, Lublin 1998, s. 49-52. Ten rodzaj świadczeń powodował jednak pewne nadużycia, które polegały na naliczaniu przez kapłanów wygórowanych należności. Aby uniknąć takich sytuacji w Kościele były powszechnie stosowane taksy opłat iura stolae. Zob. APL, ChKGK, sygn. 604, s. 438-439.

${ }^{56}$ APL, ChKGK, sygn. 101, k. 24.

${ }^{57}$ „Niwami” określano dawniej pasy ziemi często o granicach naturalnych w postaci rowów, łąk, lasów. „Niwą” określano także parcele o kształcie wydłużonym, a niezbyt szerokie.

${ }^{58}$ APL, ChKGK, sygn. 107, k. 263.

${ }^{59}$ Niestety nie ustalona jest pojemność korca zamojskiego, można jedynie domyślać, że nie odbiegał on zbytnio od korca przedrozbiorowego. Korzec - polska przedrozbiorowa jednostka miar 
na błocie na czterech kosiarzy, a druga na nieokreślonej Dąbrowie „na kosiarza jednego". Wielkość ta oznaczała, że czterech kosiarzy, kosząc od wschodu do zachodu słońca, potrzebowało na jej skoszenie jednego dnia, zaś jeden cztery dni ${ }^{60}$. Ponadto był ogród, na którym stała plebania. W przypadku dziesięciny jest informacje, że paroch z niej nie korzystał, ponieważ za zgodą Ordynata wybierali ją księża tomaszowscy.

\section{Plebania i zabudowania gospodarcze}

Dom, w którym mieszka paroch, nazywany jest plebanią lub proboszczówką. W przeszłości był to zwykle obiekt pobudowany w pobliżu świątyni, który zmieniał swoich mieszkańców czy też posesorów zgodnie z tym, jak zmieniali się kolejni rządcy parafii. Nie wiadomo, kiedy powstała w Szarowoli pierwsza plebania i towarzyszące jej budynki. Można przypuszczać, że w czasie budowy pierwszej cerkwi lub niewiele później. Wiadomo także, że plebanie często ulegały zniszczeniu z powodu pożarów i innych zdarzeń losowych. Duży wpływ na taki stan rzeczy miał także nietrwały materiał - drewno, z jakiego były zbudowane.

Pierwsza, a zarazem jedyna wzmianka źródłowa o proboszczówce i zabudowaniach gospodarczych pochodzi dopiero z protokołu wizytacji z $1743 \mathrm{r}^{61}$ W przypadku plebani jest zapis: „Ogród jeden, na którym stoi plebania, to jest piekarnia z komorą". Natomiast zabudowania gospodarcze stanowiło gumno, w skład którego wchodziła „stodółka i obórka, dylowane" ${ }^{2}$. W protokole widoczny jest brak informacji o kurniku czy też innym pomieszczeniu dla ptactwa domowego, które tam z całą pewnością było, gdyż trudno wyobrazić sobie gospodarstwo wiejskie bez kur, kaczek czy też gęsi.

\section{Duchowieństwo}

Wśród duchowieństwa parafialnego naczelną pozycję zajmował pleban (proboszcz), któremu podlegali pozostali duchowni działający przy kościele parafialnym. Decydujący wpływ na wybór plebana mieli w ówczesnym czasie kolatorzy

pojemności ciał sypkich. 1 korzec=32 garncy, 1 korzec=120,605 litra, 1 garniec= 3,7689 litra. Zob. I. Ihnatowicz, Vademecum do badań nad historia XIX i XX wieku, cz. I, Warszawa 1967, s. 42.

${ }^{60}$ Podobnie była określana powierzchnia pola ornego na ilość dni orania, co oznaczało, w ciągu ilu dni oracz mógł je całe zaorać, orząc od wschodu do zachodu słońca. Szerzej zob. J. Szymański, Nauki pomocnicze historii, Warszawa 2005, s. 182-183.

${ }^{61}$ APL, ChKGK, sygn. 107, k. 263.

${ }^{62}$ Gumno - w dawnych gospodarstwach rolnych przestrzeń między zabudowaniami gospodarskimi; podwórze gospodarskie otoczone spichrzami, stodołami i brogami. Służyło do składowania zwiezionego zboża i jego młócenia. Określano tak również budynek, w którym przechowywano snopy przed wymłóceniem oraz plac w stodole, o twardej ubitej ziemi, na którym cepami młócono zboże. Zob. M. Karolczuk-Kędzierska, Gumno, w: Wielka encyklopedia Polski, t. 3, red. M. Karolczuk-Kędzierska, Kraków 2004, s. 224. Dyl, bal - drewno tarte lub ciosane grubości 50-100 mm. Zob. B.M. Seniuk, Osiemnastowieczna terminologia z zakresu architektury i sztuki cerkiewnej oraz organizacji kościoła wschodniego. Materiaty do stownika na podstawie protokołów wizytacyjnych Eparchii Włodzimierskiej, w: Polska Ukraina 1000 lat sąsiedztwa, t. 5, red. S. Stępień, Przemyśl 2000, s. 325 
kościołów parafialnych, którzy przedstawiali kandydata biskupowi ${ }^{63}$. Proboszcz więc był prawnie zatwierdzonym - stałym, w zasadzie nieusuwalnym duszpasterzem w określonej parafii. Także majątek parafialny znajdował się pod jego zarządem. Podobną grupę duchownych stanowili administratorzy, którzy byli tymczasowymi zarządcami majątku parafialnego i opiekunami duchowymi powierzonych im parafian ${ }^{64}$.

Odtworzenie pełnej obsady cerkwi w Szarowoli w badanym okresie jest niemożliwe z powodu luk w źródłach. Dane dotyczące duchowieństwa omawianej parafii są niepełne i zupełnie przypadkowe. W wizytacji z 1720 r. zanotowano parocha, Bazylego Obuchowiecza który miał wówczas 32 lata, a w 1743 r. - 55 lat ${ }^{65}$. W związku z powyższym można ustalić, że paroch ten urodził się w $1688 \mathrm{r}$., i że być może parafia ta była jego pierwszym miejscem pracy ${ }^{66}$. Dzięki Rejestrowi zmarlych kaptanów $w$ diecezjach chetmskiej i betskiej od r. 1759 aprila, to jest od zaczęcia biskupstwa przeze mnie Maxymiliana Rytto, wiadomo, że paroch ten zmarł 31 marca 1775 r. ${ }^{67}$ mając około 87 lat. Chociaż nieznane jest pochodzenie społeczne ks. Bazylego Obuchowicza, można sądzić, że był synem kapłana, podobnie jak zdecydowana większość duchownych unickich w Rzeczypospolitej ${ }^{68}$. Wpływ na to zjawisko miało kilka czynników. Synowie prezbiterów od najmłodszych lat byli przygotowywani do pełnienia posługi cerkiewnej, co przy ówczesnym systemie kształcenia księży miało ogromne znaczenie. Ponadto święcenia kapłańskie, podobnie jak w Kościele łacińskim, mógł przyjąć tylko człowiek wolny ${ }^{69}$. Byli nimi, oprócz szlachty i mieszczan z królewszczyzn, także dzieci popów.

${ }^{63}$ Kolator (collator) - patron sprawujący aktualnie opiekę materialną nad cerkwią, posiadający prawo opiniowania kandydatów na proboszczów. Zob. Seniuk, Osiemnastowieczna terminologia z zakresu architektury i sztuki cerkiewnej, s. 337.

${ }^{64}$ Staranie się o objęcie beneficjum parafialnego w charakterze proboszcza wymagało sporo zabiegów. Najpierw należało zdać egzamin konkursowy. Następnie należało zgłosić się do władz kościelnych ze stosownymi dokumentami takimi jak: metryka urodzenia, życiorys, opinia dziekana i prezenta od kolatora parafii. Wszystkie te dokumenty po rozpatrzeniu przez władze diecezjalne w Chełmie, przesyłane były do władz wojewódzkich administracji państwowej, które jeśli nie znalazły przeszkody, przesyłały je do Komisji Rządowej Spraw Wewnętrznych i Duchownych w Warszawie. Tam była podejmowana ostateczna decyzja, po której, jeżeli była pozytywna, kandydat składał stosowną przysięgę i dopiero wówczas był ,instalowany” na proboszcza przez odpowiedniego dziekana. Wszystkie te zabiegi wymagały kosztów, czasu i niekoniecznie kończyły się powodzeniem. Zob. Kołbuk, Duchowieństwo unickie w Królestwie Polskim, s. 65-77.

${ }^{65}$ APL, ChKGK, sygn. 101, k. 24; sygn. 107, k. 263.

${ }^{66}$ Według przepisów prawa kościelnego święcenia kapłańskie można było uzyskać w wieku 24 lat.

${ }^{67}$ APL, ChKGK, sygn. 636, s. 820.

${ }^{68}$ Bieńkowski, Organizacja Kościoła wschodniego w Polsce, s. 963-964; S. Nabywaniec, Unicka Archidiecezja Kijowska w okresie rządów arcybiskupa metropolity Felicjana Filipa Wołodkowicza 1762-1778, Rzeszów 1998, s. 377-378.

69 „Prawo polskie czyniło szlachcica właścicielem wszystkich ludzi na jego gruncie rodzących się, którzy nie byli szlachtą. Los takowych ludzi zależał zupełnie od właściciela wsi, nie wolno więc było żadnemu poddanemu przyjąć stanu duchownego bez pozwolenia, czyli emancypacji dziedzica, którą albo należało okupić, albo się ukryć, żeby dziedzic nie wiedział, gdzie się jego poddany 
Jeżeli dodamy, że w diecezji chełmskiej praktycznie nie było szlachty unickiej ${ }^{70}$, a duchowieństwo unickie niechętnie odnosiło się do ludzi z zewnątrz, stanowiących konkurencję dla synów kapłańskich, to teza, że popowicze obejmowali stanowiska po swoich ojcach może okazać się jak najbardziej prawdziwa ${ }^{71}$. Można domniemywać również, że odnotowany w protokołach wizytacji w 1739 r. i 1766 r. parafii w Chodywańcach paroch Stefan Obuchowicz, oraz w 1777 r. Szymon Obuchowicz byli krewnymi, a Stefan być może był nawet bratem parocha szarowolskiego $^{72}$.

Podstawowym obowiązkiem duszpasterskim było odprawianie nabożeństw i udzielanie posług religijnych (chrzty, śluby, pogrzeby, spowiedź). Ważnym elementem pracy księdza było także nauczanie prawd wiary. Sprowadzało się ono do niedzielnego i świątecznego odmawiania pacierza i katechizacji ludu. Ponadto plebani byli zarządcami majątku parafialnego. Do ich obowiązków należało także prowadzenie akt stanu cywilnego, wykonywanie rozporządzeń władz zwierzchnich, a także dawanie wiernym przykładu moralnego prowadzenia się i wzorców chrześcijańskiego życia. $Z$ reguły duchowni wypełniali te powinności w sposób prawidłowy, zgodnie z zasadami Cerkwi, chociaż zdarzały się i odstępstwa w tym zakresie.

Niestety, brak jest materiałów źródłowych, informujących o pracy duszpasterskiej księży w parafii Szarowola. Jak zauważyła Hanna Dylągowa, poziom wiedzy religijnej wiernych był odbiciem poziomu duchownych. Niewiele umiejący ksiądz niewiele mógł nauczyć swych parafian, zwłaszcza że ci ostatni najczęściej byli chłopami i nie korzystali z innych źródeł oświaty ${ }^{73}$.

\section{Wierni}

Istotnym czynnikiem, mającym wpływ na funkcjonowanie parafii jest liczba wiernych. Jednak informacje dotyczące unitów w parochii szarowolskiej są dość ubogie. Pierwszych bardzo ogólnych danych w tym zakresie dostarcza protokół sporządzony po wizytacji w 1720 r., gdzie zaznaczono, że parafia obejmowała swoim zasięgiem unitów zamieszkałych w tej $\mathrm{wsi}^{74}$. Szczegółowych danych dostarcza jednak dopiero wizytacja przeprowadzona w 1743 r. $^{75}$ Zanotowano wów-

podział. W takim stanie rzeczy [przyjęcie] zależało od zwierzchności duchownej, ponieważ przystępujący do stanu duchownego musiał okazać metrykę swego urodzenia. Jeżeli jej pleban nie wydał, z jakim konceptem ukrywającym poddaństwo, trzeba było wielkiej względności egzaminatorów i archidiakona na egzaminie prezydującego.” Zob. H. Kołłątaj, Pamiętnik o stanie Kościoła polskiego katolickiego i o wszystkich innych wyznaniach w Polszcze, w: Stan oświecenia w Polsce w ostatnich latach panowania Augusta III (1750-1764), oprac. J. Hulewicz, Wrocław 1953, s. 209-210.

${ }^{70}$ Bieńkowski, Organizacja Kościoła wschodniego w Polsce, s. 963.

${ }^{71} \mathrm{~W}$ latach 1754-1759 w diecezji chełmskiej co najmniej 81\% przyjmujących święcenia było synami duchownych. Zob. W. Bobryk, Duchowieństwo unickiej diecezji chetmskiej w XVIII wieku, Lublin 2005, s. 135.

${ }^{72}$ APL, ChKGK, sygn. 105, k. 418; sygn. 113, k. 45v; sygn. 120, k. 218.

${ }^{73}$ Dylągowa, Dzieje unii brzeskiej (1596-1918), s. 41.

${ }^{74}$ APL, ChKGK, sygn. 101, k. 24.

${ }^{75}$ Tamże, sygn. 110, s. 392. 
czas, że parafię zamieszkiwało 20 wiernych mogących przyjmować sakramenty. Oczywiście wykaz wiernych przystępujących do poszczególnych sakramentów nie pozwala nam na określenie liczby parafian, ale może dostarczyć podstawowych informacji o stanie i dynamice zaludnienia parafii, a także umożliwia opisanie jej struktury demograficznej. Jednak wyciąganie na tej podstawie wniosków na temat liczby wiernych w parafii nie jest pewne i może prowadzić do dużych nieścisłości. Mając tego typu dane i chcąc oszacować ogólną liczbę wiernych należy (za Cezarym Kuklo) do komunikujących doliczyć co najmniej 25\% wiernych, gdyż taką liczbę stanowiły dzieci młodsze ${ }^{76}$. Stosując ten wskaźnik można określić, że w 1743 r. parafia liczyła tylko około 25 wiernych.

Trudno jest określić, co miało wpływ na tak niewielką liczbę wiernych w tej parafii w 1. połowie XVIII stulecia. Należy jednak zaznaczyć, że nie był to przypadek odosobniony. W pobliskiej parafii pw. św. Michała Archanioła w Rogóźnie w 1772 r. odnotowano 16, a w 1748 już tylko 13 parafian ${ }^{77}$. W parafii pw. Protekcji NMP w Ciotuszy w 1744 r. było 24, a w 1761 aż 150 parafian, zaś w parafii pw. Nawiedzenia NMP w Maziłach w 1744 r. było 30, a w 1761 już 100 wiernych $^{78}$. W analizowanych źródłach nie podano przyczyn tego zjawiska, ale można domniemywać, że na niewielkie ilości wiernych w parafiach miały wpływ klęski elementarne (działania wojenne, przemarsze wojsk koronnych i obcych, głód i epidemie). Co prawda w badanych źródłach nie odnaleziono informacji mówiących o wyżej wspomnianych zjawiskach w Szarowoli, jednak dość licznie poświadczone są one dla odległego o ok. $8 \mathrm{~km}$ Tomaszowa. W związku z powyższym może domniemywać, że były one udziałem zarówno Szarowoli, jak również innych niezbyt odległych miejscowości (Rogóźna, Ciotuszy, Maził, Łosińca). I tak w latach 1704-1709 przechodziły przez Tomaszów wojska kozackie, saskie oraz rosyjskie, które nawet w 1707 r. stacjonowały w mieście. Oprócz wojsk obcych, Tomaszów był często nawiedzany także przez wojska koronne ${ }^{79}$. W kwietniu 1705 r. wybuchła w mieście epidemia morowego powietrza, która, jak podaje zapis w księdze cerkiewnej, przyszła ze Lwowa. Mieszkańcy miasta kryli się przed nią w pobliskich wsiach, w tym w Łosińcu i Wólce Łosiniec$\mathrm{kiej}^{80}$. Niewykluczone jest, że schronienia przez zarazą mieszczanie szukali także i w Szarowoli. Ciężkim okresem dla Tomaszowa i całej Ordynacji były lata 17151716, w związku z konfederacją zawiązaną w Tarnogrodzie. Wojska konfederackie po porażce pod Sokalem przemieściły się w kierunku Tomaszowa i Bełza, gdzie atakowały pomniejsze jednostki saskie, nie stroniąc od łupieżczych wypraw na pobliskie miasta $\mathrm{i}$ wsie ${ }^{81}$.

Jednym z najistotniejszych aspektów charakterystyki społeczności parafialnej pozostaje zagadnienie kształtowania się jej poziomu religijnego i moralnego. Nie-

${ }^{76}$ C. Kuklo, Demografia Rzeczypospolitej przedrozbiorowej, Warszawa 2009, s. 74.

${ }^{77}$ APL, ChKGK, sygn. 536, k. 6v, 10v.

${ }^{78}$ Tamże, sygn. 107, k. 269v, 271; sygn. 110, s. 483, 488.

${ }^{79}$ APL, Księgi miasta Tomaszowa, sygn. 5, k. 71, 77-79, 102-102v, 120, 123-123v, 440v; APL, Parafia rzymskokatolicka Tomaszów, sygn. 2, s. 50.

${ }^{80}$ APL, Parafia greckokatolicka Tomaszów, sygn. 8, s. 1.

${ }^{81}$ J. Wimmer, Wojsko Rzeczypospolitej w dobie wojny pótnocnej, Warszawa 1956, s. 418. 
stety, w przypadku omawianej parafii nie dysponujemy źródłami, które pozwoliłyby na określenie stanu religijności tamtejszej wspólnoty religijnej.

\section{Zakończenie}

$\mathrm{Na}$ podstawie przedstawionych źródeł wynika, że funkcjonowanie parafii unickiej pw. Wniebowzięcia Pańskiego w Szarowoli można opisać jedynie w 1. połowie XVIII w. Trudno ustalić czas powstania tej wspólnoty wiernych. Należy sądzić, że została utworzona po zawarciu unii brzeskiej w miejsce wcześniej działającej parafii prawosławnej. Dlatego można się jedynie domyślać, że jednostka ta, podobnie jak i inne parafie w ciągu pierwszych lat istnienia, otrzymała konieczne podstawy ekonomiczne i wyposażenie do obrzędowości unickiej. Paramenty liturgiczne zmieniały się i były uzupełniane przez okres funkcjonowania parafii.

Niewiele wiadomo na temat warunków mieszkaniowych parocha, źródła bardzo lakonicznie wspominają o tym tylko dwa razy. Podobnie przedstawia się sytuacja w przypadku budynków gospodarczych. Także dane dotyczące liczby wiernych są bardzo ubogie. Określenie liczby wiernych jest szczególnie trudne dla XVIII stulecia, kiedy to wizytatorzy nie badali szczegółowo tego zjawiska, kontentując się jedynie pobieżnymi wyliczeniami. Podobnie w obsadzie cerkwi, udało się ustalić tylko jednego duchownego.

Artykuł nie zamyka tematu, a odkrycie wcześniejszych źródeł pozwoli na pogłębienie wiadomości o funkcjonowaniu tej parafii w XVII stuleciu.

\section{Źródła rękopiśmienne}

\section{BIBLIOGRAFIA}

Archiwum Główne Akt Dawnych w Warszawie

Archiwum Skarbu Koronnego, sygn. 36

Archiwum Państwowe w Lublinie

Chełmski Konsystorz Grecko-Katolicki, sygn. 101, 105, 107, 110, 113, 120, 139, 147, $148,149,150,151,154,228,604,636$

Księgi miasta Tomaszowa, sygn. 5

Parafia rzymskokatolicka Tomaszów, sygn. 2

Parafia greckokatolicka Tomaszów, sygn. 8

\section{Źródla drukowane}

Źródła dziejowe, t. XVIII, cz. 1, Polska XVI w. pod względem geograficzno-statystycznym, t. VII, cz. 1, Ziemie Ruskie. Ruś Czerwona, opisane przez Aleksandra Jabłonowskiego, Warszawa 1902. 


\section{Opracowania}

Bieńkowski L., Diecezja prawosławna, w: Encyklopedia katolicka, t. 3, red. R. Łukaszyk, L. Bieńkowski, F. Gryglewicz, Lublin 1988, kol. 132.

Bieńkowski L., Organizacja Kościoła Wschodniego w Polsce, w: Kościót w Polsce, t. 2, red. J. Kłoczowski, Kraków 1970, s. 782-1050.

Bobryk W., Duchowieństwo unickiej diecezji chetmskiej w XVIII w., Lublin 2005.

Chodynicki K., Kościół prawosławny a Rzeczpospolita Polska. Zarys historyczny 13701632, Warszawa 1934.

Chruscewicz G., Istorija zamojskago sobora (1720 goda), Wilno 1880.

Czterechsetlecie zawarcia Unii Brzeskiej 1596-1996: materiaty sesji naukowej zorganizowanej $w$ Toruniu $w$ dniach 28-29 listopada 1996 r., red. S. Alexandrowicz, T. Kempa, Toruń 1998.

400-lecie unii brzeskiej, red. K. Soczyński, Warszawa 1996.

Dydycz A.P., Opisanie odnalezienia relikwii św. Jozafata Kuncewicza na tle jego życia oraz dziejów doczesnych szczątków, „Rocznik Bialskopodlaski”, 12 (2004) s. 159176.

Dylągowa H., Dzieje unii brzeskiej (1596-1918), Warszawa 1996.

Dziedzictwo Unii Brzeskiej, red. R. Dobrowolski, M. Zemło, Lublin-Supraśl 2012.

Frykowski J.A., Dzieje parafii unickiej pw. św. Michała w Łosińcu do 1875 r., „Historia i Świat", 4 (2015) s. 237-266.

Gil A., Prawostawna Eparchia Chetmska do 1596 r., Lublin-Chełm 1999.

Gil A., Chetmska diecezja unicka 1596-1810. Dzieje i organizacja. Studia i materiaty $z$ dziejów chrześcijaństwa wschodniego w Rzeczpospolitej, Lublin 2005.

Gil A., Chetmskie diecezje obrządku wschodniego. Zagadnienia organizacji terytorialnej w XVII i XVIII w., w: Polska-Ukraina. 1000 lat sąsiedztwa, t. 5, red. S. Stępień, Przemyśl 2000, s. 29-61.

Gil A., Chetmska Diecezja Unicka w okresie rządów biskupa Jakuba Suszy (1649-1687), w: Sztuka sakralna i duchowość pogranicza polsko-ukraińskiego na Lubelszczyźnie (Materiaty z Międzynarodowej Konferencji ,,Sztuka Sakralna Pogranicza”, Lublin 13-15.10.2005 r.), red. S. Batruch, R. Zilionko, Lublin 2005, s. 61-66.

Gil A., Skoczylas I., Kościoły wschodnie w państwie polsko-litewskim w procesie przemian i adaptacji: Metropolia kijowska w latach 1458-1795, Lublin-Lwów 2014.

Gloger Z., Geografia historyczna ziem dawnej Polski, Kraków 1903.

Górak J., Kościoły drewniane Zamojszczyzny, Zamość 1986.

Górak J., Dawne cerkwie drewniane w dawnym województwie zamojskim, Zamość 1984.

Ihnatowicz I., Vademecum do badań nad historia XIX $i$ XX w., cz. I, Warszawa 1967.

Janeczek A., Osadnictwo pogranicza polsko-ruskiego. Województwo betskie od schyłku XIV do poczatku XVII w., Warszawa 1993.

Karbownik M., Ofiary iura stolae na ziemiach polskich w latach 1285-1918, Lublin 1995.

Karbownik M., Opodatkowanie duchowieństwa i dóbr kościelnych na ziemiach polskich w okresie zaborów 1772-1918, Lublin 1998.

Karbownik M., Ciężary stanu duchownego na rzecz państwa od r. 1381 do połowy XVII w., Lublin 1980.

Karolczuk-Kedzierska M., Gumno, w: Wielka encyklopedia Polski, t. 3, red. M. Karolczuk-Kędzierska, Kraków 2004.

Kość J., Stownictwo regionalne w XVII-XVIII-wiecznych księgach miejskich wschodniej Lubelszczyzny, w: Studia językoznawcze. Streszczenia prac doktorskich, t. 13, red. W. Boryś, Wrocław 1988, s. 57-102.

Kołbuk W., Duchowieństwo unickie w Królestwie Polskim 1835-1875, Lublin 1992. 
Kołbuk W., Kościoły wschodnie w Rzeczypospolitej około 1772 r., Lublin 1998.

Kołbuk W., Kościoły wschodnie na ziemiach dawnej Rzeczypospolitej 1772-1914, Lublin 1992.

Kołłątaj H., Pamiętnik o stanie Kościoła polskiego katolickiego i o wszystkich innych wyznaniach w Polszcze, w: Stan oświecenia w Polsce $w$ ostatnich latach panowania Augusta III (1750-1764), oprac. J. Hulewicz, Wrocław 1953, s. 209-210.

Koziej J., Parafia, w: Encyklopedia katolicka, t. 14, red. E. Gigilewicz, Lublin 2010, kol. 1324-1326.

Kuklo C., Demografia Rzeczypospolitej przedrozbiorowej, Warszawa 2009.

Kumor G., Geneza i zawarcie unii brzeskiej, w: Unia brzeska, geneza, dzieje i konsekwencje w kulturze narodów słowiańskich, red. R. Łużny, F. Ziejka, A. Kępiński, Kraków 1994, s. 26-44.

Lewandowski J., Greckokatolicka diecezja chetmska $w$ realiach polityczno-ustrojowych Księstwa Warszawskiego, „Annales Universitatis Mariae Curie-Skłodowska”, Sectio F, Historia, vol. LXII, Lublin 2007, s. 77-84.

Librowski S., Wizytacje diecezji wrocławskiej, cz. 1, Wizytacje diecezji kujawsko-pomorskie, t. 1, Opracowanie archiwalno-źródtoznawcze, z. 1, Wstęp ogólny, „Archiwa, Biblioteki i Muzea Kościelne”, 8 (1964) s. 5-186.

Likowski E., Dzieje Kościoła unickiego na Litwie i Rusi w XVIII i XIX w. uważane głównie ze względu na przyczyny jego upadku, t. 1, Warszawa 1906.

Likowski E., Unia brzeska, Warszawa 1907.

Litak S., Akta wizytacyjne parafii z XVI-XVIII w. jako źródło historyczne, „Zeszyty Naukowe KUL", 5 (1962) nr 3, s. 41-58.

Markunas A., Uczitiel T., Popularny słownik sakaralizmów polskich i ukraińskich, Poznań 2001.

Mironowicz A, Struktura organizacyjna kościoła prawosławnego w Polsce $w$ X-XVIII w., w: Kościót prawosławny w Polsce dawniej i dziś, red. L. Adamczuk, A. Mironowicz, Warszawa 1993.

Nabywaniec S., Unicka Archidiecezja Kijowska w okresie rząów arcybiskupa metropolity Felicjana Filipa Wołodkowicza 1762-1778, Rzeszów 1998.

Narbutt O., Historia i typologia ksiag liturgicznych bizantyńsko-słowiańskich. Zagadnienie identyfikacji wedtug kryterium treściowego, Warszawa 1979.

Niedźwiedź J., Leksykon historyczny miejscowości dawnego województwa zamojskiego, Zamość 2004.

Nowodworski M., Parafia, w: Encyklopedia kościelna, t. 16, red. M. Nowodworski, Warszawa 1892, s. 200.

Peter J., Z przeszłości miasta kresowego, Zamość 1947.

Półćwiartek J., Z badań nad rola gospodarczo-społeczna plebanii na wsi pańszczyźnianej ziemi przemyskiej i sanockiej w XVI-XIX w., Rzeszów 1974.

Слободян В., Церкви Холмскоі епархї̈, Львів 2005.

Snela B., Kolory liturgiczne, w: Encyklopedia katolicka, t. 9, red. A. Szostek, Lublin 2002, kol. 385-386.

Seniuk B.M., Osiemnastowieczna terminologia z zakresu architektury i sztuki cerkiewnej oraz organizacji kościoła wschodniego. Materiały do słownika na podstawie protokołów wizytacyjnych Eparchii Włodzimierskiej, w: Polska-Ukraina 1000 lat sąsiedztwa, t. 5, red. S. Stępień, Przemyśl 2000, s. 309-346.

Soszyński R., 400-lecie unii brzeskiej, Warszawa 1996.

Stownik polsko-cerkiewnosłowiańsko-ukraiński Teodora Witwickiego z połowy XIX w., oprac. J. Dzendzeliwski, Warszawa 1997. 
Słownik Języka Polskiego przez M. Bogumiła Samuela Linde (1811), t. II, cz. II, Drukarnia XX. Pijarów, Warszawa 1811.

Sygowski P., Wizytacja cerkwi unickiej diecezji chetmskiej przeprowadzonej w latach 1720-1725 przez biskupa chetmskiego i betskiego Józefa Lewickiego, ,Studia archiwalne", 2 (2007) s. 199-232.

Szymański J., Nauki pomocnicze historii, Warszawa 2005.

Turnau I., Stownik ubiorów. Tkaniny, wyroby pozatkackie, skóry, broń i klejnoty oraz barwy znane w Polsce od średniowiecza do poczatku XIX w., Warszawa 1999.

Unia brzeska 1596 r. Geneza i skutki. Katalog wystawy, Toruń 1997.

Unia brzeska. Materiaty z radomskiego sympozjum, red. A. Hejda, Radom 1998.

Unia brzeska, geneza, dzieje i konsekwencje $w$ kulturze narodów stowiańskich, ed. R. Łużny, F. Ziejka, A. Kępiński, Wrocław 1994.

Wimmer J., Wojsko Rzeczypospolitej w dobie wojny pótnocnej, Warszawa 1956.

Wójcik E., Fundacja, w: Encyklopedia katolicka, t. 5, red. L. Bieńkowski, Lublin 1989, kol. 760-761.

Wyczawski H.E., Wprowadzenie do studiów w archiwach kościelnych, Warszawa 1956.

Zajda A, Nazwy staropolskich powinności feudalnych, danin i optat (do 1600 r.), Warszawa 1979.

\section{Z DZIEJÓW PARAFII UNICKIEJ PW. WNIEBOWZIĘCIA PAŃSKIEGO W SZAROWOLI, W ŚWIETLE XVIII-WIECZNYCH WIZYTACJI KOŚCIELNYCh}

\section{Streszczenie}

Wieś Szarowola położona jest w gminie Tomaszów Lubelski, w północnej części powiatu tomaszowskiego, w województwie lubelskim. Lokowana została w 1579 r. na gruntach wsi Rogóźna, w miejscu zwanym Porebrody, przez popa Kunata. W okresie staropolskim administracyjnie związana była z powiatem i województwem bełskim. Po I rozbiorze Polski znalazła się w monarchii Habsburgów, w okresie napoleońskim w Księstwie Warszawskim, a po Kongresie Wiedeńskim w zależnym od Rosji Królestwie Polskim.

Pierwotnie funkcjonowała tam parafia prawosławna, a po zawarciu unii brzeskiej, unicka. Jako samodzielna jednostka kościelna przetrwała do końca XVIII wieku, kiedy została przez władze austriackie zdegradowana do miana cerkwi filialnej i włączona do parafii w Łosińcu, w której funkcjonowała do likwidacji unii. Przez pierwszy okres funkcjonowania parafia w Szarowoli organizacyjnie przynależna była do dekanatu tyszowieckiego, a pod koniec XVII w. do nowoutworzonej protopopi tomaszowskiej.

Analizując protokoły powizytacyjne biskupów chełmskich, przedstawiono wygląd świątyni parafialnej i jej wyposażenie, a także zmiany jakie zachodziły w tym zakresie w badanym okresie. Ustalono, ze parochowi do utrzymania służyły grunty orne i łąki, dzięki którym prowadził gospodarstwo, a ponadto różnorodne opłaty od wiernych. Duchowny miał do swojej dyspozycji niewielką plebanię wraz z zabudowaniami gospodarczymi. $\mathrm{W}$ miarę możliwości określono beneficjum cerkiewne i pokazano zachodzące $\mathrm{w}$ nim zmiany w badanym okresie. Na koniec zwrócono uwagę na liczbę wiernych oraz odtworzono liczbę duszpasterzy pracujących w tej parafii.

Słowa kluczowe: parafia unicka; cerkiew; paroch; unici; uposażenie; utensylia; paramenty 


\title{
THE HISTORY OF THE UNIATE PARISH DEDICATED TO THE ASCENSION OF OUR LORD IN SZAROWOLA IN THE LIGHT OF THE EIGHTEENTH- CENTURY CHURCH VISITATIONS
}

\begin{abstract}
Summary
The village of Szarowola is located in the district of Tomaszów Lubelski, in the northern part of the poviat of Tomaszów, in the province of Lublin. It was founded in 1579 in the land of the village of Rogóźno, in the place called Porebrody, by the Orthodox priest Kunat. In the Old Polish period, it was part of the district and proviat of Bełz. After the fist partition of Poland it was in the Habsburg Monarchy, in the Napoleonic period in the Duchy of Warsaw, and after the Congress of Vienna in the Polish Kingdom, which was dependant on Russia.

Originally, in that village there was an orthodox parish, and after the proclamation of the Union of Brest, a Uniate one. As an independent church unit, it survived until the end of the eighteenth century, when it was relegated by the Austrian authorities to the affiliate Uniate church and included in the parish of Łosiniec, where it functioned until the liquidation of the union. During the first period of its existence the parish of Szarowola organizationally was part of the deanery of Tyszowce, and at the end of the seventeenth century part of a newly created protopope's district of Tomaszów.

Analyzing the post-visitation protocols of the Bishops of Chelm, the author presented the appearance of the parish church and its furnishings, as well as the changes taking place during the period under study. It was established that the parish priest (paroch) supported himself by cultivation of arable land and meadows, which enabled him to run a farm, and he also received money from the faithful. The clergyman had a small presbytery with outbuildings at his disposal. In addition, the article attempted to show benefices of the Orthodox Church and the changes in the period under study. Finally, the author drew attention to the number of the faithful and priests working in the parish.
\end{abstract}

Keywords: Uniate parish; Uniate church; paroch; the Uniates; salary; paraphernalia; paraments 